\title{
H. H. CHAPMAN GIVEN INTERNATIONAL FORESTRY AWARD
}

Herman Haupt Chapman of New Haven, Conn., professor emeritus of forest management at Yale University and past president of the Society of American Foresters, was awarded the Sir William Schlich memorial medal on December 17 at the annual meeting of the Society held in Boston, Mass.

The Schlich memorial medal, awarded for distinguished service in forestry, had been previously presented to only four other persons: Franklin D. Roosevelt, Gifford Pinchot, Henry S. Graves, and William B. Greeley. Presentation of the medal to Dr. Chapman was made by Clyde S. Martin, president of the Society of American Foresters and manager of forestry relations for the Weyerhaeuser Timber Company, Tacoma, Wash.

In honor of Sir William Schlich, an eminent international leader in forestry, a fund was established fifteen years ago by foresters of Englishspeaking nations in recognition of Sir William's great services to forestry in India, England, and throughout the world. The Society of American Foresters is custodian of the periodic grants made to the United States by the Schlich Memorial Foundation, and from time to time awards the medal for noteworthy achievement in the advancement of forestry.

A graduate of the University of Minnesota in 1899 in science and agriculture, Prof. Chapman obtained the master of forestry degree at Yale University in 1904, and then entered the Bureau of Forestry, now the U.S. Forest Service.

He joined the faculty of the Yale School of Forestry in 1906, and while there became widely known for his championing of the individual rights and responsibilities of foresters and in safeguarding the interests of the public. His vision and integrity have been the inspiration of countless students. As a researcher of forest problems in many sections of the country, especially in the South, he is the author of many technical articles, bulletins and textbooks.

Elected a Fellow of the Society of American Foresters in 1922, he served as president of that organization during the period 1934-1937. In 1947 the degree doctor of science, honoris causa, was conferred upon him by the University of Minnesota.

\section{FORESTRY DIRECTORY OF THE PROVINCE OF QUEBEC}

The 1949 edition of the above directory has just been distributed by the Canada Indexing and Publishing Co., 13 Place d'Aiguillon, Quebec, P.Q. In addition to listing those engaged in forest products industries, interesting and useful statistics are presented. Dr. A. R. Gobeil is the editor, and the directory is priced at $\$ 5.00$. 